\title{
PELATIHAN PENGOLAHAN LIMBAH TANAMAN MANGROVE SEBAGAI BAHAN PEWARNA ALAMI PADA PRODUK ECOPRINT DI DESA LUBUK KERTANG KABUPATEN LANGKAT, SUMATERA UTARA
}

\author{
Iwan Risnasari ${ }^{1,2}$, Deni Elfiati ${ }^{1,2}$, Arif Nuryawan ${ }^{1,2}$, Harisyah Manurung ${ }^{1}$, Mohammad \\ Basyuni $^{1,2}$, Apri Heri Iswanto ${ }^{1,2}$, Erman Munir $^{3}$, Bejo Slamet ${ }^{1,2}$ dan Arida Susilowati ${ }^{1,2}$ \\ ${ }^{1}$ Program Studi Kehutanan, Fakultas Kehutanan Universitas Sumatera Utara. \\ Jln. Tridharma Ujung No. 1 Kampus USU Medan, 20155 \\ ${ }^{2}$ Pusat Unggulan Iptek Mangrove, Universitas Sumatera Utara \\ ${ }^{3}$ Fakultas Matematika dan Ilmu Pengetahuan Alam Universitas Sumatera Utara. \\ Jl. Bioteknologi No.1 Kampus USU Medan, 20155
}

iwan1@usu.ac.id, deni1@usu.ac.id, arif5@usu.ac.id, harisyah_manurung@usu.ac.id, m.basyuni@usu.ac.id, apri@usu.ac.id, erman2@usu.ac.id, bejo@usu.ac.id, arida.susilowati@usu.ac.id,

\begin{abstract}
Lubuk Kertang Village has the potential for mangrove ecotourism which is currently being developed as a source of income for the community's economy apart from fishermen and agriculture. Even the mangrove ecosystem in Lubuk Kertang Village has become a tourist icon for Langkat. Apart from mangrove ecotourism, Lubuk Kertang is also unique with its processed mangrove products in the form of foods such as mangrove dodol, jeruju crackers, and mangrove syrup. However, productivity is constrained by the availability of mangrove fruit which depends on the season. Moving on from this, it is necessary to carry out community service activities to provide education about the potential and benefits of mangrove waste in the form of stems, twigs, leaves, and fruit from other aspects. Namely that apart from being processed as food material, mangrove waste can also be processed into other high-value products, one of which is a natural dye. Activities carried out are in the form of socialization and education about the potential and benefits of mangrove waste as a natural coloring agent to the manufacturing process. Furthermore, the natural dyes that have been produced are applied in the coloring process through the ecoprint workshop/training. The media used are cloth/textiles, paper, sheepskin, and ceramics (mugs). The response of the community, represented by women from independent women farmer groups as well as some students of Madrasah Tsanawiyah and the Village Head was very good. Even some mothers from independent women farmer groups routinely continue to make ecoprints in the form of cloth, pashmina, and t-shirts. Their products have also been included in exhibition activities in Lubuk Kertang Village. The Head of Lubuk Kertang Village hopes that there will be sustainability from independent women farmer groups to make ecoprint products to increase income from the Lubuk Kertang community.
\end{abstract}

Keywords: mangrove plants; mangrove waste; natural dyes; ecoprint

\begin{abstract}
Abstrak
Desa Lubuk Kertang memiliki potensi ekowisata mangrove yang saat ini terus dikembangkan sebagai salah satu pemasukan sumber pendapatan ekonomi masyarakat selain nelayan dan pertanian. Bahkan ekosistem mangrove di Desa Lubuk Kertang menjadi ikon wisata Langkat. Selain ekowisata mangrove, Lubuk Kertang juga khas dengan produk olahan mangrovenya berupa makanan seperti dodol mangrove, kerupuk jeruju dan sirup dari buah mangrove. Namun produktivitasnya terkendala oleh ketersediaan buah
\end{abstract}


mangrove yang tergantung dengan musim. Beranjak dari hal tersebut maka perlu dilakukan kegiatan pengabdian pada masyarakat untuk memberikan edukasi tentang potensi dan manfaat limbah tanaman mangrove baik berupa batang, ranting, daun dan buah dari aspek yang lain. Yaitu bahwa selain dapat diolah sebagai bahan pangan limbah tanaman mangrove juga dapat diolah menjadi produk bernilai tinggi lainnya, salah satunya sebagai pewarna alami. Kegiatan yang dilakukan adalah dalam bentuk sosialisasi dan edukasi tentang potensi dan manfaat limbah tanaman mangrove sebagai zat pewarna alami hingga proses pembuatannya. Selanjutnya pewarna alami yang telah dihasilkan diaplikasikan dalam proses pewarnaan melalui kegiatan workshop/pelatihan ecoprint. Media yang digunakan adalah kain/tekstil, kertas, kulit domba dan keramik (mug). Respon masyarakat yang diwakili oleh ibu-ibu kelompok tani wanita mandiri serta beberapa siswa Madrasah Tsanawiyah dan Kepala Desa sangat baik. Bahkan beberapa ibu-ibu dari kelompok tani wanita mandiri secara rutin terus membuat olahan ecoprint berupa kain, pashmina dan kaos. Hasil produksi mereka juga telah diikutserakan pada kegiatan pameran di Desa Lubuk Kertang. Kepala Desa Lubuk Kertang mengharapkan adanya keberlanjutan dari kelompok tani wanita mandiri untuk membuat produk-produk ecoprint dalam rangka menambah pemasukan dari masyarakat Lubuk Kertang.

Kata kunci : tanaman mangrove; limbah mangrove; pewarna alami; ecoprint

\section{PENDAHULUAN}

Ekosistem mangrove mempunyai peran yang sangat penting di wilayah pesisir. Sekitar 3 juta hektare hutan mangrove tumbuh di sepanjang 95.000 kilometer pesisir Indonesia. Jumlah ini mewakili 23\% dari keseluruhan ekosistem mangrove dunia (Giri et al. 2011). Selain termasuk wilayah yang terluas di dunia ekosistem mangrove Indonesia Juga memiliki keanekaragaman jenis yang tertinggi di dunia. Hutan mangrove ditemukan di banyak wilayah Indonesia, dan ekosistem mangrove regional penting ada di Papua, Kalimantan dan Sumatera (FAO, 2007). Ekosistem mangrove yang cukup penting di Sumatera Utara terletak di Desa Lubuk Kertang, Kecamatan Berandan Barat, Kabupaten Langkat dengan luasan kurang lebih 638.47 ha. Jenis- jenis mangrove yang ditemukan di Desa Lubuk Kertang antara lain Avicennia marina, A. lanata, Bruguiera sexangula, Rhizophora apiculata, Ceriops tagal, Xylocarpus granatum, Lumnizera racemosa, Sonneratia caseolaris, Excoearia agallocha dan Acanthus ilicifolius (Basyuni et al. 2016).

Ekosistem mangrove di Lubuk Kertang memiliki keunikan tersendiri, karena sempat mengalami kerusakan yang parah pada periode 1999-20012. Namun muncul kesadaran akan lingkungan pada masyarakat hingga akhirnya berhasil memulihkan hutan mangrove. Berbagai penghargaan pun telah diraih dan menjadi contoh sukses model perhutanan sosial, bahkan hutan mangrove Lubuk Kertang menjadi ikon wisata Langkat. Selain ekowisata mangrove, Lubuk Kertang juga khas dengan produk olahan mangrovenya. Masyarakat desa terutama kaum ibu, mengolah tanaman mangrove berupa buah dan daunnya menjadi berbagai macam makanan seperti dodol, kerupuk dan sirup hingga dapat meningkatkan nilai ekonomi dari tanaman mangrove tersebut.

Satu potensi lagi pemanfaatan tanaman mangrove yang akhir-akhir ini mulai dikembangkan adalah sebagai 
bahan pewarna alami. Hampir semua bagian dari tanaman mangrove, yaitu daun, buah, batang dan akar dapat menghasilkan bahan pewarna alami. Beberapa hasil pengolahan tanaman mangrove untuk bahan pewarna alami dan pewarna batik seperti buah Rhizopora mucronate, daun dan batang Sorenasia alba, Rizophora sp, Avecenia $s p$, Ceripos decandra, dan Lumicera sp dapat menghasilkan pewarna yang tidak mudah luntur (Dewi et al. 2016; Dewi et al. 2018; Pringgenies et al. 2013; Pringgenies et al. 2017; Paryanto et al. 2015). Hal ini sangat relevan dengan isu lingkungan, karena data menunjukkan bahwa $17-20 \%$ pencemaran air yang disebabkan oleh industri berasal dari aktivitas pewarnaan dan finishing tekstil. Pewarna sintetis dalam proses produksi dan aplikasinya meninggalkan bahan/limbah berbahaya (Ogugbue dan Sawidis 2011; Jain dan Vasantha, 2016).

Salah satu teknik pewarnaan alami yang berkembang beberapa tahun ini adalah ecoprint (ecoprinting), dimana dalam teknik tersebut tidak hanya menghasilkan warna tetapi juga dapat terbentuk pola (jejak) pada media yang berasal dari berbagia bagian tanaman tersebut. Teknik ecoprint diartikan sebagai proses mentransfer warna dan bentuk/pola ke permukaan kain melalui kontak langsung antara kain dan daun. Transfer warna tersebut dimungkinkan karena daun memiliki pigmen warna yang akan keluar melalui proses pemanasan/pengukusan. Dalam perkembangannya teknik ecoprint kemudian dapat diaplikasikan juga pada media lain seperti kulit hewan, kertas dan kayu (Saraswati dan Sulandjari, 2018; Fazruza, 2018; Larasati 2019). Dengan melihat potensi tanaman mangrove yang ada di Desa Lubuk Kertang, maka sangat memungkinkan untuk dikembangkan pengolahan limbah tanaman mangrove sebagai pewarna alami dengan teknik ecoprint.

\section{TINJAUAN LITERATUR}

Sumber pewarna alami adalah tumbuhan, binatang dan mikroorganisme. Zat pewarna alam lebih banyak terdapat pada tumbuhan. Untuk mengambil zat pewarna tersebut harus diekstrak/ fermentasi dari bagian tumbuhan yang mengandung zat warna paling banyak (daun, kayu, kulit kayu, akar, bunga, kulit buah, buah, biji atau kulit biji (Ogugbue dan Sawidis, 2011; Teli dan Shastrakar, 2014; Kim dan Shin, 2011). Zat warna alam merupakan komponen organik dengan gugus hidroksil pada struktur molekulnya. Karena memiliki gugus hidroksil maka memungkinkan pewarna alami ini bisa terikat oleh media berlignoselulosa seperti kain, kertas dan kayu. Pewarna alami juga mempunyai sifat kelarutan dalam air yang rendah karena beberapa zat warna alam tidak mempunyai gugus pelarut (Purwar 2016; Zamri et al. 2012). Dilihat dari beberapa aspek, zat warna alam berpotensi menggantikan penggunaan zat warna sintetis, karena mudah terdegradasi di alam dan bersifat terbarukan. Zat warna alam untuk bahan tesktil, umumnya diperoleh dari ekstrak bagian tumbuhan seperti: akar, kayu, daun, biji, dan bunga (Sinha et al. 2012). 
Salah satu teknik pewarnaan alami yang berkembang beberapa tahun ini adalah ecoprint (ecoprinting). Ecoprint diartikan sebagai proses mentransfer warna dan bentuk/pola pada kain melalui kontak langsung antara kain dan daun tanpa menggunakan bahan kimia. Transfer warna tersebut dimungkinkan karena daun memiliki pigmen warna yang akan keluar melalui proses pemanasan/pengukusan. Selain daun, bunga dan batang daun juga dapat mengeluarkan warna yang ditransfer ke permukaan media berlignoselulosa. Keunikan dari ecoprint adalah warna yang akan dihasilkan pada pola jejak daun/bunga akan berbeda meskipun dari jenis yang sama (Kumar dan Prabha 2018; Arif dan Marsudi 2019; Arifah et al. 2019; Nurcahyanti dan Septiana 2018).

Masyarakat Desa Lubuk Kertang sudah memanfaatkan tanaman mangrove, seperti daun dan buah mangrove sebagai bahan baku pembuatan kerupuk, dodol dan sirup (Basyuni et al. 2016). Namun permasalahan dalam pengolahan tersebut adalah terkait dengan musim, dimana buah mangrove tidak tersedia dalam waktu yang terus menerus. Sehingga hal tersebut akan mempengaruhi produktifitas pengolahannya. Sementara pemanfaatannya sebagai bahan pewarna alami dan bentuk pada media selulosa masih belum banyak dikenal di lingkungan tersebut. Pewarna alami dapat diperoleh dari bagian daun, ranting, batang dan kulit tanaman mangrove yang biasanya diperoleh oleh petani mangrove dalam kegiatan perawatan melalui pemangkasan secara berkala. Ketrampilan menghasilkan pewarna alami dan aplikasinya pada media dengan teknik ecoprint hingga menjadi produk bernilai tinggi sangat memungkinkan utk diterapkan pada masyarakat desa Lubuk Kertang. Karena keterampilan tersebut dapat di lakukan dengan peralatan yang sederhana dan tidak memerlukan bakat/keahlian khusus seperti melukis atau menggambar

\section{METODE PELAKSANAAN}

Metode pelaksanaan kegiatan pengabdian yang dilakukan adalah sebagai berikut:

1) Kegiatan Sosialisasi dan edukasi tentang manfaat dan potensi limbah tanaman mangrove sebagai pewarna alami dan proses pewarnaan pada media dengan teknik ecoprint pada mayarakat. Kegiatan ini demi mendorong dan memotivasi masyarakat dalam memanfaatkan limbah tanaman mangrove sebagai pewarna alami

2) Kegiatan sosialisasi tentang pembuatan pewarna alami dari limbah tanaman mangrove (dari bagian batang, ranting, kulit dan buah) meliputi kegiatan pengeringan dan perebusan hingga menjadi larutan pewarna atau larutan mordant (untuk treatment pada media)

3) Workshop/pelatihan ecoprint pada media kain, kertas, mug dan kulit domba meliputi kegiatan treatment pada media 
(kain/kertas/kulit domba/mug), penyiapan pewarna alami, penyiapan daun/bunga dan treatment terhadap daun. Selanjutnya proses pewarnaan pada media (kain/kertas/kulit domba/mug) diikuti oleh penataan daun dan bunga pada media tersebut diakhiri dengan perebusan/pengukusan. Hasil perebusan/pengukusan dibuka dan dikeringkan.

\section{HASIL DAN PEMBAHASAN}

Sebelum kegiatan pengabdian dilakukan terlebih dahulu dilakukan koordinasi dan sosialisasi rencana kegiatan antara tim Pengabdian Program Desa Binaan USU dengan pihak mitra. Koordinasi yang dilakukan berkaitan dengan peserta pelatihan, kepastian jadwal pelatihan dan teknis pelaksanaan agar berjalan sesuai target dengan tetap menjalankan protokol pencegahan penyebaran virus covid-19. Kepala Desa menetapkan bahwa peserta pelatihan ecoprint adalah perwakilan siswa Madrasah Tsanawiyah Madinatul Ilmi dan Kelompok Wanita Tani Mandiri yang berjumlah 20 orang. Setelah koordinasi dan sosialisasi kegiatan dilakukan pengambilan sampel berupa dedaunan dan kulit berbagai jenis tanaman mangrove yang ada di ekosistem hutan mangrove Lubuk Kertang. Tujuan pengambilan sampel adalah untuk uji coba limbah tanaman mangrove sebagai pewarna alami dan dedaunan mangrove sebagai motif/pola pada kain.
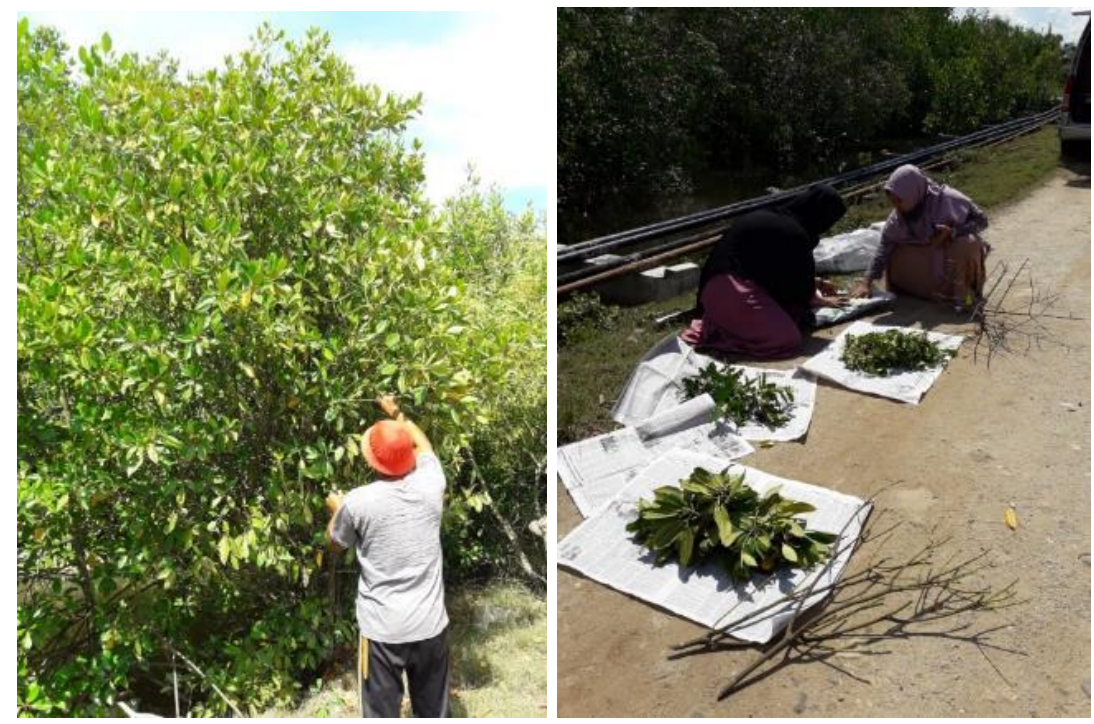

Gambar 1. Pengambilan sampel ranting, batang dan dedaunan tanaman mangrove

Jenis-jenis yag diperoleh dari ekosisten hutan mangrove di Lubuk Kertang antara lain jenis Api-api (Avicennia lanata), Bakau Minyak (Rhizophora apiculata), Bakau
(Rhizophora mucronata), Cingam (Scyphiphora hydrophyllacea), Butabuta (Excoecaria agallocha), Jeruju (Acanthus ilicifolius), Lenggadai (Bruguiera parviflora), Perepat/pedada 
(Sonneratia caseolaris). Menurut Basyuni et al (2016) masyarakat sebagian besar melakukan kegiatan pemanfaatan kawasan mangrove Lubuk Kertang berupa pengolahan hasil buah dan daun mangrove. Buah mangrove biasanya mereka olah menjadi sirup/dodol, sementara daunnya diolah menjadi kerupuk mangrove.

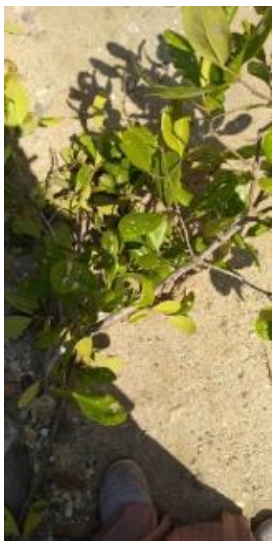

(a)

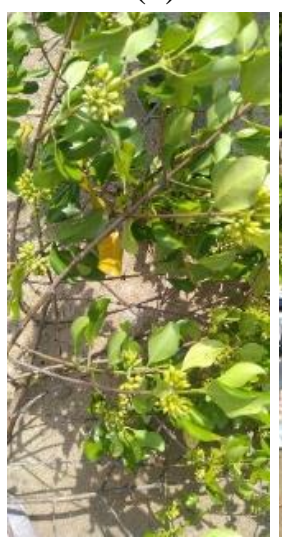

(f)

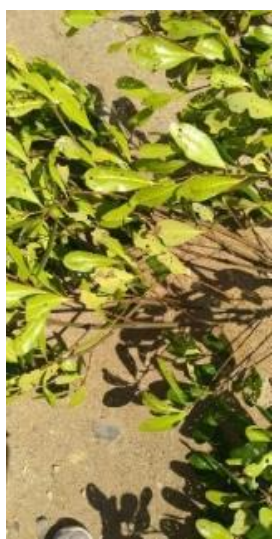

(b)

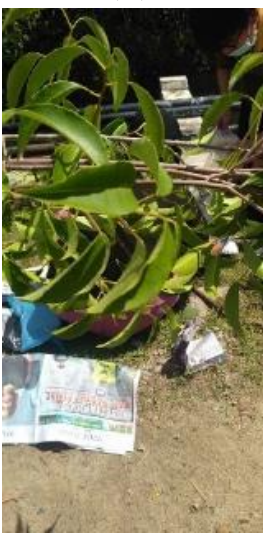

(g)

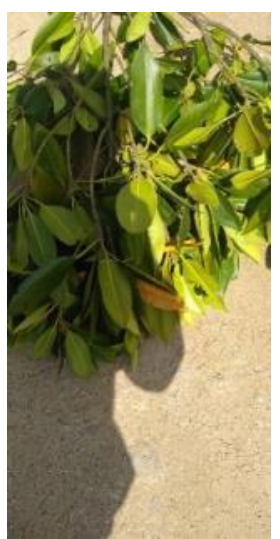

(c)

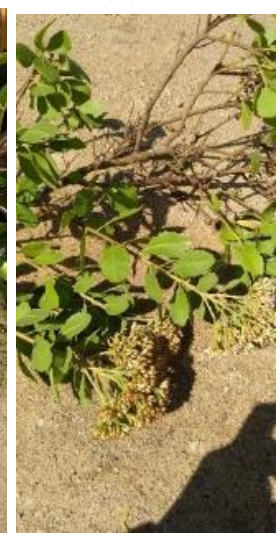

(h)

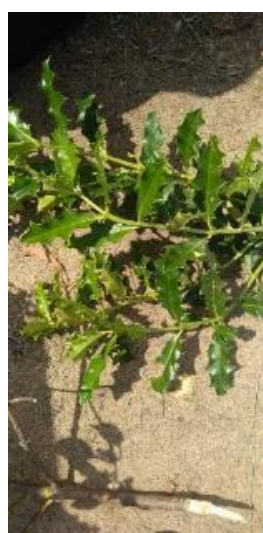

(d)

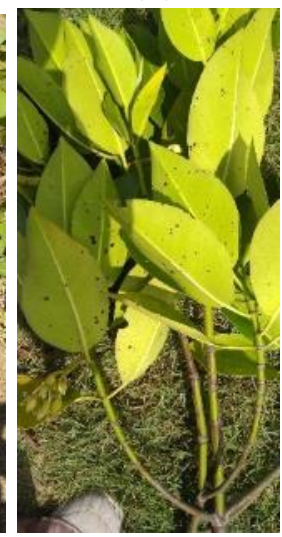

(i)

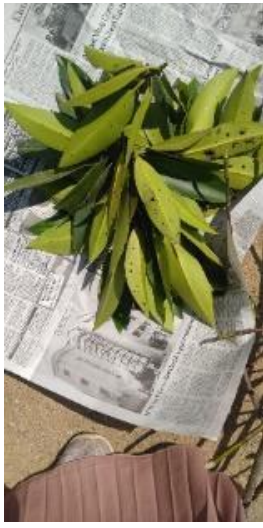

(e)

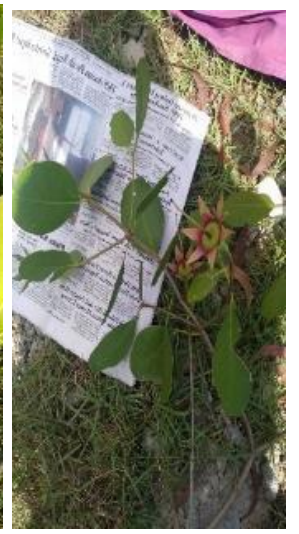

(j)

Gambar 2. Jenis-jenis daun mangrove di Lubuk Kertang: a) api-api; b) api-api2; c) lenggade; d) jeruju; e) bakau; f) Cingam; g) buta-buta; h) beluntas; i) bakau minyak; j) pedada

Sampel ranting/cabang mangrove yang diambil untuk uji coba sebelum kegiatan pelatihan, dipotong-potong kemudian diproses menjadi pewarna alami dengan metode sederhana, yaitu melalui perebusan dengan perbandingan 1:10 dengan pelarut (air). Sebagai penguat warna ditambahkan bahan simplokos sebanyak 2 sendok makan. Setelah itu dilakukan proses mordant pada kain dengan tujuan untuk membersihkan dan membuka serat-serat kain sehingga siap untuk berikatan dengan pewarna alami dari bakau minyak dan motif/pola dari dedaunan (Elsahida et al. 2019; Jahanggiri et al. 2018). Selanjutnya kain yang telah dimordant direndam dalam larutan pewarna bakau minyak hingga warna terserap dengan sempurna oleh kain. 


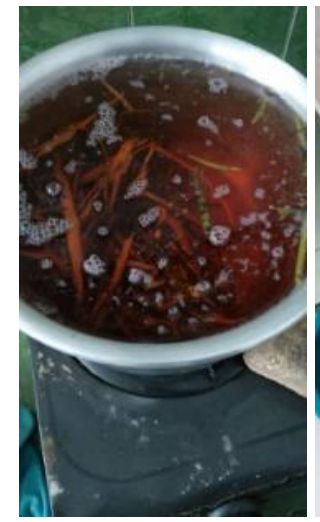

(a)

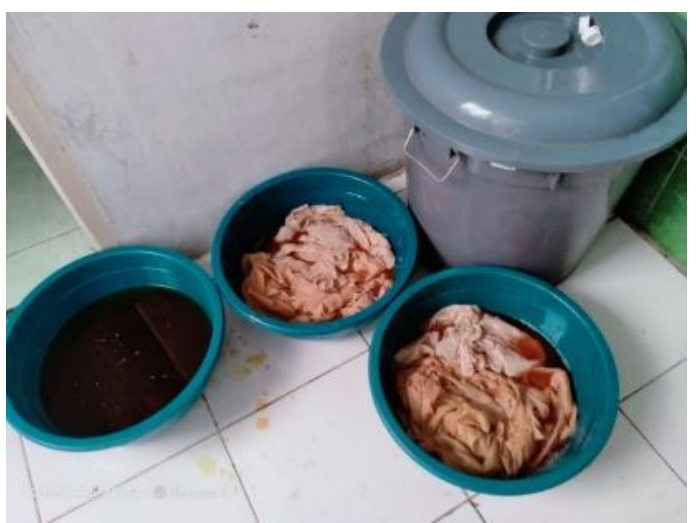

(b)

Gambar 3. Uji coba pewarna alami: a) perebusan potongan ranting/cabang bakau minyak sebagai pewarna; b) proses mordant kain dan pewarnaan kain dengan larutan bakau minyak

Gambar 4 (a) menunjukkan proses penataan daun pada permukaan kain yang telah direndam oleh larutan pewarna bakau minyak. Setelah penataan daun kemudian dilakukan proses pengukusan untuk proses transfer pewarna alami dan motif dedaunan pada permukaan kain. Motif/pola daun yang tercetak pada permukaan kain sangat dipengaruhi oleh pigmen daun yang akan mengeluarkan warna dan pola yang jelas dengan bantuan panas melalui proses pengukusan (Maharani 2018). Hasil

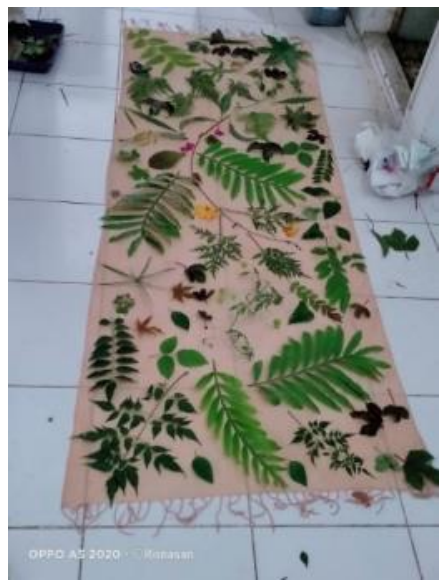

(a) setelah pengukusan menunjukkan bahwa larutan bakau minyak menghasilkan warna keabuan sampai kemerahan tergantung jenis tanin yang digunakan dalam proses mordant kain, dan semua bentuk dan warna daun tercetak dengan jelas. Hal ini menunjukkan bahwa larutan bakau minyak yang diketahui mengandung tanin dapat berfungsi sebagai pendukung bahan mordant untuk mengikat warna dan pola daun pada permukaan kain.

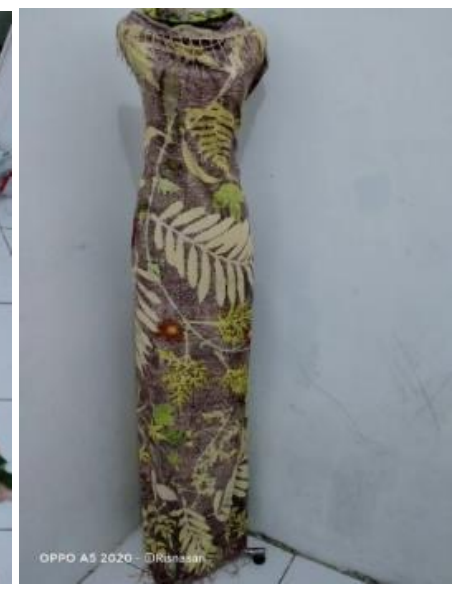

(b)

Gambar 4. Proses penataan daun pada kain :a) sebelum pengukusan dan b) hasil kain ecoprint dengan pewarna dari rebusan bakau minyak 
Daun-daun mangrove yang digunakan sebagai motiv atau pola pada kain semuanya mengeluarkan jejak dengan cukup jelas dengan warna kuning kehijauan hingga hijau. Hal ini diduga bahwa hampir semua jenis daun mangrove mengandung tanin, sehingga pada saat proses pengukusan

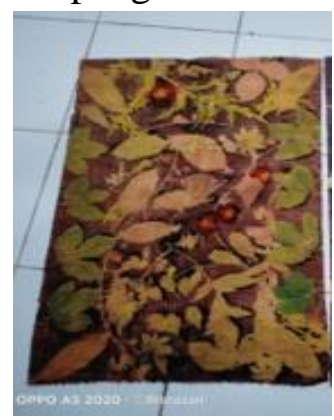

mengeluarkan warna yang dapat terserap dengan jelas oleh media kain dibawahnya. Dengan demikian semua bagian tanaman mangrove berpotensi untuk dimanfaatkan sebagai bahan pewarna alami dan motif/pola ecoprint pada media kain.

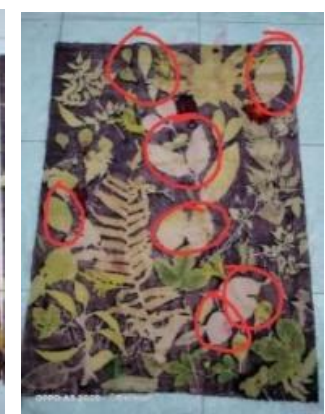

Gambar 5. Hasil kain ecoprint dengan pewarna bakau minyak dan motif atau pola menggunakan berbagai jenis daun mangrove

Pelaksanaan kegiatan pelatihan ecoprint diawali dengan pembukaan dan sambutan yang dilakukan oleh Kepala Desa Lubuk Kertang dengan dihadiri oleh ketua BPD (Badan Permusyawaratan Desa) Lubuk Kertang. Setelah acara pembukaan selanjutnya adalah pemaparan teori, yang diawali dengan pameran kecil-kecilan atau display produk ecoprint berupa selendang/pashmina, blocnote, dan lainlain dengan tujuan untuk memberikan gambaran kepada para peserta pelatihan tentang berbagai media dan produk yang nantinya bisa dihasilkan dan memiliki nilai jual yang tinggi. Sehingga para peserta dapat termotivasi untuk bisa meneruskan keterampilan yang telah diperoleh setelah menyelesaikan pelatihannya. Hari pertama kegiatan Pelatihan dimulai dengan pemaparan teori tentang pewarnaan alami, jenis tumbuhan dan bagian tumbuhan dari tanaman mangrove yang berpotensi sebagai bahan pewarna alami serta proses pengolahannya. Kemudian bahan kain yang dapat digunakan dalam proses pewarnaan alami dan bagaimana memberikan perlakuan terhadap kain tersebut.

Selanjutnya diberikan satu set bahan dan peralatan kepada masingmasing peserta untuk melakukan praktek secara langsung. Kegiatan pertama adalah ecoprint dengan metode basic yaitu ecoprint dengan media kain dan hanya menggunakan daun-daunan/tanpa menggunakan pewarna. Tujuannya untuk mengenalkan konsep tentang jejak daun pada media kain, beberapa jenis daun yang memiliki jejak dan warna kuat pada kain. 

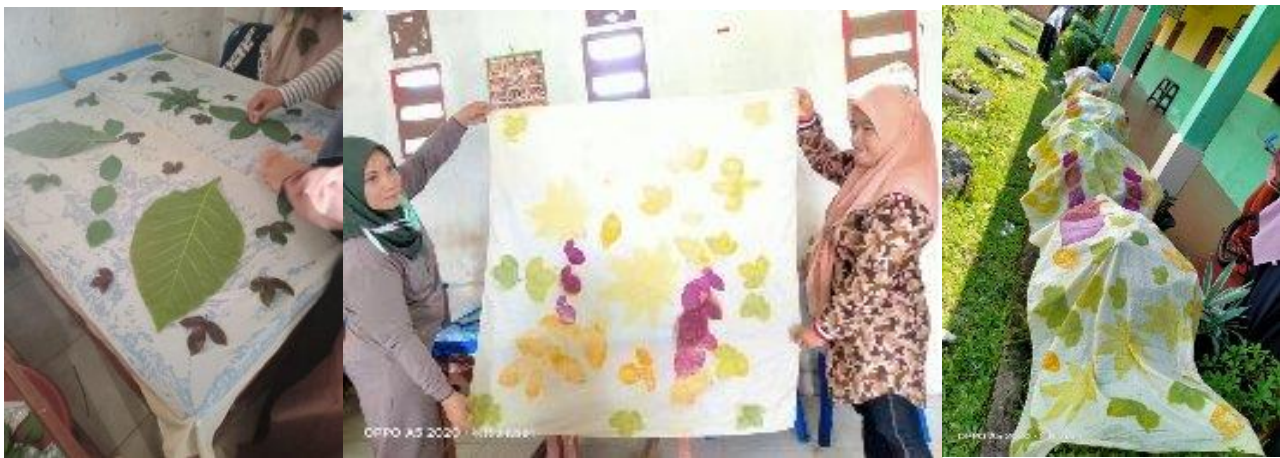

Gambar 6. Praktik Ecoprint Metode Basic dan Hasil Kain Ecoprint Metode Basic

Setelah proses penataan daun pada kain dilanjutkan dengan proses pengukusan selama kurang lebih 2 jam. Sambal menunggu waktu pengukusan, dilanjukan dengan praktek ecoprint metode pounding (getok) dengan media kain kanvas yang sudah berbentuk goodiebag. Metode pounding adalah metode memindahkan pola/jejak dan warna daun langsung ke media kain dengan cara memukul/getok dengan palu kayu (Arif dan Marsudi 2019). Kemudian dilanjutkan dengan praktek ecoprint metode botanical, yaitu menggunakan media kain yang berbentuk selendang. Metode botanical dilakukan dengan menggunakan 2 kain (kain utama dan kain blanket/selimut), pada kain utama dilakukan pewarnaan dengan mencelupkan/merendamnya ke larutan pewarna alami. Sementara kain blanket direndam dalam larutan tunjung dengan tujuan agar senyawa tannin sebagai bahan pendukung mordant pada kain utama dapat bereaksi dengan tunjung (Prabhu dan Teli 2014). Pewarna alami yang digunakan pada praktek tersebut adalah rebusan kayu secang (Caesalpinia Sappan Linn) dan kayu bakau minyak (Rhizophora apiculata). Setelah direndam pewarna dilanjutkan dengan proses penataan daun dan pengukusan kain selama kurang lebih 2 jam.

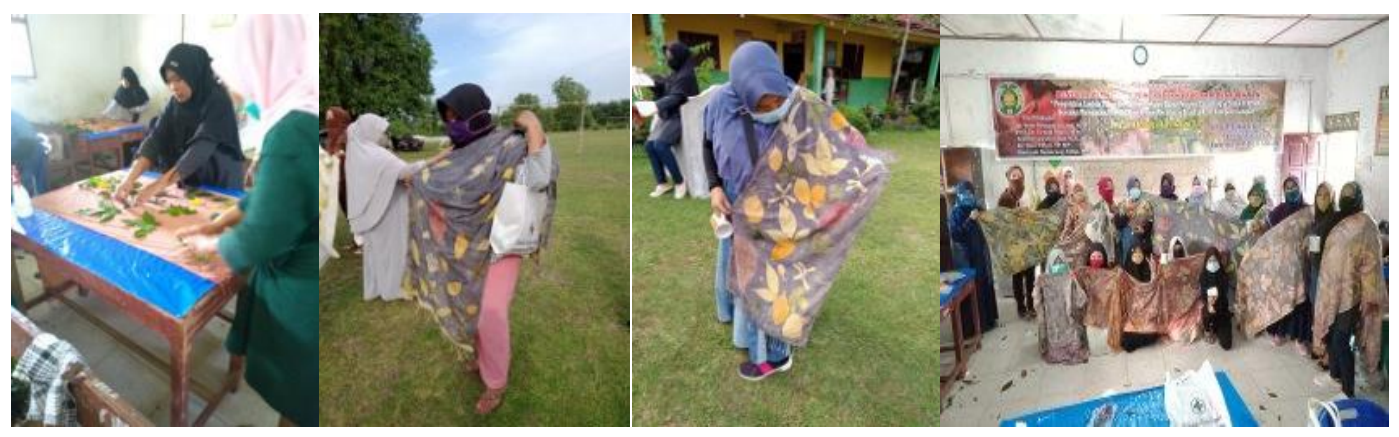

Gambar 7. Praktik Ecoprint Metode Botanical

Materi praktek pada hari kedua adalah ecoprint pada media kulit, mug dan kertas. Prinsip ecoprint pada kulit dan kertas kureng lebih sama dengan ecoprint pada media kain. Namun kulit dan kertas lebih sensitif erhadap panas, sehingga suhu pada saat perebusan/pengukusan harus di jaga agar tidak merusak bahan. Hasil ecoprint pada media kulit selanjutnya dapat 
dibuat menjadi bermacam-macam produk seperti sepatu, tas, casing HP, dompet dan lain-lain. Sementara ecoprint pada media kertas dapat dibuat menjadi produk berupa blocnote, binder, kipas tangan, pembatas buku, hiasan dinding, tempat tissue dan lai-lain.
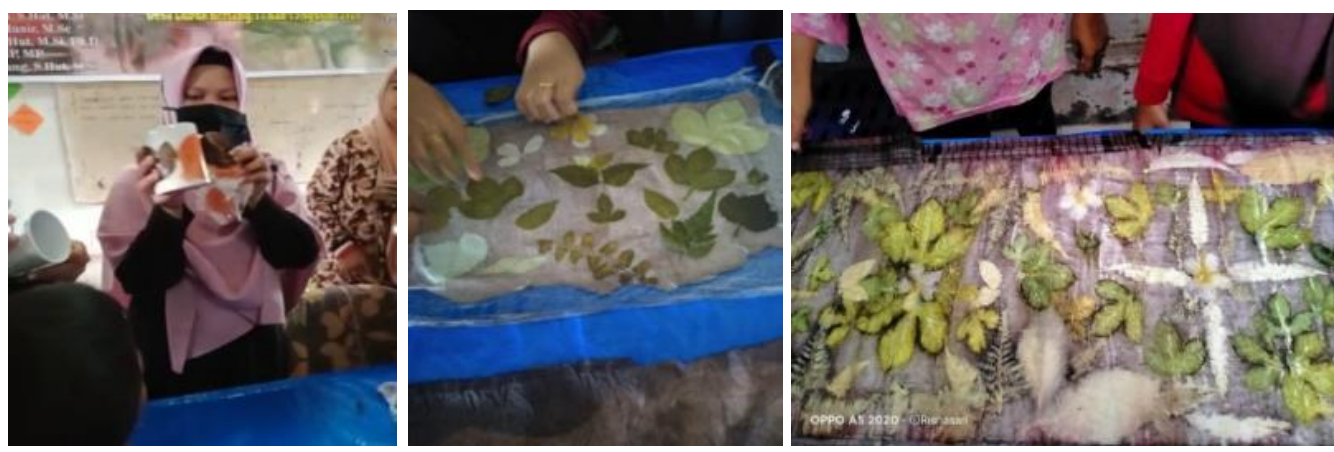

Gambar 8. Hasil Praktek Ecoprint pada media mug, kulit dan kertas

Para peserta pelatihan dan Kepala Desa di akhir acara menyatakan bahwa pelatihan tersebut membuka wawasan mereka bahwa banyak bahan-bahan alam yang ada disekitar tempat tinggal mereka dapat dibuat menjadi produk bernilai tinggi. Demikian juga Kepala Desa Sei Glugur berharap kegiatan tidak hanya berhenti pada pelatihan saja, namun dapat berkesinambungan sehingga dapat meningkatkan perekonomian masyarakat setempat. Selain itu juga diharapkan kegiatan pengabdian ini bisa menjadi langkah awal menuju program desa wisata hijau yang telah dicanangkan sebeumnya. Beberapa peserta pelatihan bahkan tetap aktif untuk melanjutkan kegiatan ecoprint ini. Sejauh ini produk yang sudah mereka hasilkan adalah ecoprint pada kain, pashmina dan kaos serta produk turunannya berupa tas ecoprint, sarung bantal ecoprint, pouch dan lainlain. Produk-produk tersebut telah di pasarkan pada kegiatan pameran di bulan Oktober 2020 di Desa Lubuk Kertang. Ketua Kelompok Tani Wanita Mandiri menyebutkan bahwa kedepannya memiliki target untuk membuat gallery yang berisi produk-produk ecoprint dan mulai untuk membuat produk-produk turunannya seperti tas/dompet ecoprint. Untuk mendukung kegiatan tersebut tim pengabdian mencoba menghubungkan kelompok tani Wanita Mandiri dengan PT. Pertamina yang beroperasi di desa Lubuk Kertang dan melalui program CSR (corporate social responsibility) PT. Pertamina siap menjadi pendamping kelompok tersebut.
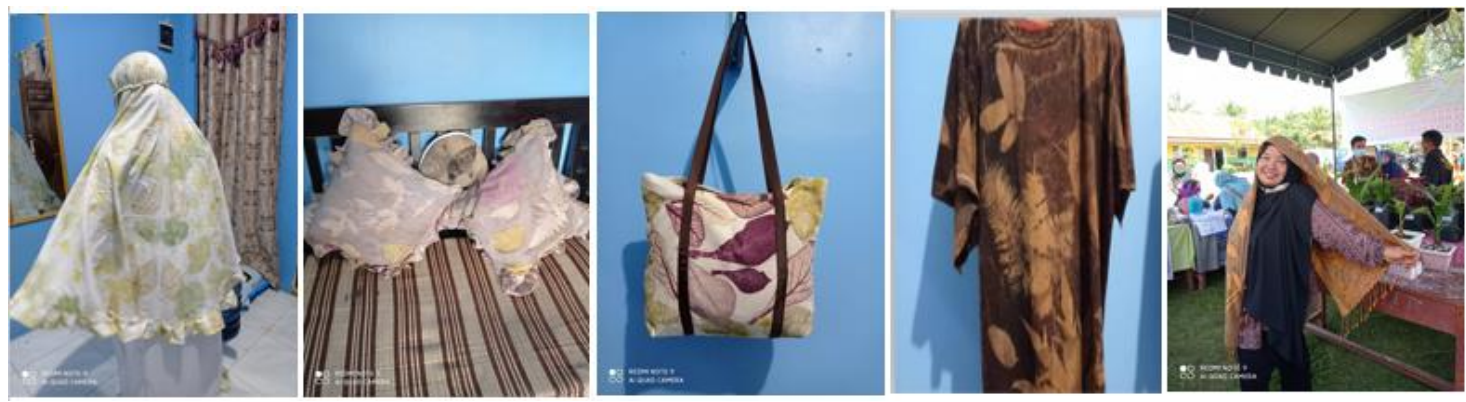

Gambar 9. Produk-produk ecoprint yang telah dihasilkan oleh Kelompok Tani Wanita Mandiri untuk mendukung ekonomi kreatif 


\section{KESIMPULAN DAN SARAN}

Dalam kegiatan Pengabdian Program Desa Binaan dengan sub topik kegiatan : 'Pengolahan Limbah Tanaman Mangrove Sebagai Bahan Pewarna Alami Dengan Teknik Ecoprint Bersama Masyarakat Di Desa Lubuk Kertang Kecamatan Brandan Barat Kabupaten Langkat' dapat disimpulkan bahwa:

1. Sosialisasi dan pelatihan diikuti oleh perwakilan masyarakat Lubuk Kertang, yaitu Kelompok Tani Wanita Mandiri dan siswa Madrasah Tsanawiyah Lubuk Kertang, telah mampu mengolah tanaman mangrove berupa kulit kayu, ranting dan daundaunan menjadi produk ecoprint

2. Kegiatan pegabdian mendapatkan sambutan yang baik dari para peserta dan Kepala Desa Lubuk Kertang dan diikuti dengan antusias

3. Kepala Desa Lubuk Kertang memberikan dukungannya kepada kelompok wanita tani mandiri untuk dapat terus menghasilkan produk ecoprint yang dapat dikomersialisasikan sehingga dapat menambah pemasukan warga dan mulai mengupayakan adanya galeri untuk menampung produk-produk tersebut.

Adapun saran dari kegiatan pengabdian ini adalah dilakukannya pendampingan yang intensif baik secara langsung maupun online terutama terkait dengan masalah pemasaran produk.

\section{UCAPAN TERIMA KASIH}

Ucapan terimakasih disampaikan kepada Rektor Universitas Sumatera Utara atas dukungan dana untuk kegiatan Pengabdian Program Desa Binaan, di Desa Lubuk Kertang, Kecamatan Brandan Barat, Kabupaten Langkat Tahun 2020.

\section{DAFTAR PUSTAKA}

Arif WF dan Marsudi. 2019. Uji Coba Warna Daun Sirih Merah Dengan Teknik Pounding Dan Steam. Jurnal Seni Rupa, Volume 07 Nomor 02 Tahun 2019, 73-80

Arifah KN, Febriyanto A, , Cendana CR, Imani DMC, Nurfitria MA dan Pustikaningsih A. Ec-Fash (Eco Culture Fashion) Inovasi Kain Tenun Kombinasi Batik Ecoprint Sebagai Upaya Melestarikan Cerita Rakyat Indonesia. Jurnal Ilmiah Penalaran dan Penelitian Mahasiswa

Basyuni M, Y Bimantara, B Slamet dan AS Thoha. 2016. Identifikasi Potensi Dan Strategi Pengembangan Ekowisata Mangrove Di Desa Lubuk Kertang, Kecamatan Brandan Barat, Kabupaten Langkat Sumatera Utara. Abdimas Talenta 1 (1) 2016: 31-38

Dewi NK, N Kariada dan F Febriana. 2016. Konsep Green Economic Melalui Penyediaan Pewarna Alami Batik Dari Tanaman 
Mangrove. Rekayasa Vol. 14

No. 2, Desember 2016.

Dewi LF, D Pringgenies dan A Ridlo. 2018. Pemanfaatan Mangrove Rhizophora mucronata Sebagai Pewarna Alami Kain Katun. Journal of Marine Research Vol.7, No.2 Mei 2018, pp. 7988, EISSN: 2407-7690

Elsahida K, Fauzi A M, Sailah I and Siregar I Z 2019 Sustainability of the use of natural dyes in the textile industry IOP Conference Series: Earth and Environmental Science 399012065

FAO. (2007). The world's mangroves 1980-2005. Rome: Food and Agriculture Organization of the United Nations.

Fazruza M. 2018. Eksplorasi Daun Jati Sebagai Zat Pewarna Alami Pada Produk Pashmina Berbahan Katun Dengan Teknik Ecoprint. Jurnal Ilmiah Mahasiswa Pendidikan Kesejahteraan Keluarga 3(3) : 116.

Giri, C., Ochieng, E., Tieszen, L. L., Zhu, Z., Singh, A., Loveland, T., .. . Duke, N. (2011). Status and distribution of mangrove forests of the world using earth observation satellite data. Global Ecology and Biogeography, 20(1), 154-159.

Jahangiri A, Ghoreishian S M, Akbari A, Norouzi M, Ghasemi M, Ghoreishian $M$ and Shafiabadi E 2018 Natural Dyeing of Wool by
Madder (Rubia tinctorum L.) Root Extract Using Tannin-based Biomordants: Colorimetric, Fastness and Tensile Assay Fibers and Polymers 19 2139-48

Jain $\mathrm{H}$ and Vasantha M. 2016. Eco Friendly Dyeing with natural dye Areca nut; enhancing colour fastness with natural mordants (Myrobalan, Lodhra and Pomegranate) and increasing the Antibacterial Activity. Arch. Appl. Sci. Res., 2016, 8 (8):1-7

Kim C and Shin Y. 2011. Eco-printing Using Chitosan and Natural Colorants(1). Textile Coloration and Finishing, Vol. 23, No. 2, 2011. ISSN(Print) 1229-0033. ISSN(Online) 2234-036X. DOI 10.5764/TCF.2011.23.2.90.

Kumar V and Prabha R. Extraction and analysis of natural dye. J. Nat. Prod. Plant Resour., 2018, 8 (2): 32-38

Larasati N. 2019. "Penerapan Motif Daun Pepaya Dan Adas Sowa Dengan Teknik Eco Printing Pada Blus." Jurnal Tata Busana. 8(2).

Maharani A. 2018. Motif Dan Pewarnaan Tekstil Di Home Industry Kaine Art Fabric "Ecoprint Natural Dye". (Yogyakarta: Universitas Negeri Yogyakarta) pp 383-94

Nurcahyanti D and Septiana U. 2018. Handmade Eco Print as a Strategy to Preserve the Originality of Ria Miranda's Designs in the Digital Age. MUDRA Journal of Art and 
Culture Vol. 33, No. 3, September 2018 p $395-400$

Ogugbue CJ and Sawidis T. 2011. Bioremediation and detoxification of synthetic wastewater containing triarylmethane dyes by Aeromonas hydrophila isolated from industrial effluent. Biotechnology Research International, 2011.

Pringgenies D, E. Supriyantini, R. Azizah, R. Hartati, Irwani dan OK Radjasa. 2013. Aplikasi Pewarnaan Bahan Alam Mangrove Untuk Bahan Batik Sebagai Diversifikasi Usaha Di Desa Binaan Kabupaten Semarang. Majalah INFO, Edisi XV, Nomor 1, Pebruari 201, ISSN : $0852-1816$

Pringgenies D, E Yudiati, RAT Nuraeni dan ES Susilo. 2017. Pemberdayaan Kelompok Wanita Nelayan Pesisir Pantai dengan Aplikasi Teknologi Pewarna Alam Limbah Mangrove Jadi Batik di Mangkang Kecamatan Tugu Semarang. Jurnal Panrita Abdi, 2017, Volume 1, Issue 2.

Paryanto, E Kwartiningsih, W Agung, SH Pranolo, V Haningtyas, R Hidayat dan I Roy. 2015. Pengambilan Zat Warna Alami Dari Buah Mangrove Spesies Rhizophora Mucronata Untuk Pewarna Batik Ramah Lingkungan. Jurnal Purifikasi, Vol. 15, No. 1
Purwar S. 2016. Application of natural dye on synthetic fabrics: A review. International Journal of Home Science 2016; 2(2): 283-287

Prabhu K H and Teli M D 2014 Ecodyeing using Tamarindus indica $\mathrm{L}$. seed coat tannin as a natural mordant for textiles with antibacterial activity Journal of Saudi Chemical Society 18 864-72

Rather LJ, Khan MA and Mohammad F. 2017. Biomordanting Potential of Acacia nilotica (Babul) in Conjunction with Kerria lacca and Rheum emodi Natural Dyes. Journal of Natural Fibers

Saraswati TJ dan S Sulandjari. 2018. Perbedaan Hasil Rok Pias Eco Print Daun Jati (Tectona Grandis) Menggunakan Jenis Dan Massa Mordan Tawas Dan Cuka. Jurnal Tata Busana 7(2).

Sinha K, Saha PD and Datta S. 2012. Natural Blue Dye from Clitoria Ternatea: Extraction and Analysis Methods. RJTA Vol. 16 No. 2 2012

Sulistiyani R. 2015. Pengaruh Proses Mordanting Dan Jenis Mordan Terhadap Kualitas Kain Celup Ikat Yang Diwarnai Dengan Zat Warna Alam Jantung Pisang. Skripsi Universitas Negeri Semarang

Teli MD, Sheikh J and Shastrakar P. 2014. Eco-friendly Antibacterial Printing of Wool Using Natural Dyes. J Textile Sci Eng, Volume 4 - Issue 2 - doi:10.4172/21658064.1000151 
Yusuf M, Shabbir M and Mohammad F. 2017. Natural Colorants: Historical, Processing and Sustainable Prospects. Natural Products and Bioprospecting, February 2017, Volume 7, Issue 1, pp 123-145
Zamri TKATM, Munaim MSA and Wahid ZA. 2012. Extraction Optimization of Natural Dye from Clitoria Ternatea Flower by OFAT. The National Conference for Postgraduate Research 2016, Universiti Malaysia Pahang 